\title{
PENGARUH PENAMBAHAN KARAGENAN TERHADAP KARAKTERISTIK PERMEN JELLY KULIT ANGGUR HITAM (Vitis vinifera)
}

\author{
Luh Dian Rna Fajarini ${ }^{1}$, I Gusti Ayu Ekawati ${ }^{2}$, Putu Timur Ina ${ }^{2}$ \\ ${ }^{1}$ Mahasiswa Program Studi Imu dan Teknologi Pangan, Fakultas Teknologi Pertanian, Unud \\ ${ }^{2}$ Dosen Program studi Imu dan Teknologi Pangan, Fakultas Teknologi Pertanian, Unud \\ E-mail: rna.dian@yahoo.com ${ }^{1}$
}

\begin{abstract}
This study aims to determine the effect of thecarrageenan on the characteristics of grape skins jelly candy and to find the right carrageenan concentration to produce jelly candy with the best characteristics. The experimental design used was randomized block design by treatment with carrageenan concentration of $1.0 \%, 1.5 \%, 2.0 \%, 2.5 \%, 3.0 \%$ and $3.5 \%$. The treatment was repeated as many as 3 repetitions then obtained 18 units of the experiment, the data obtained from the result research were analyzed by variance and if the treatment had an effect on the variable then continued with Duncan test. The results showed that the addition of carrageenan with a concentration of $2.0 \%$ was the best characteristic of grape skins jelly candy with 18.01\% moisture content, 0.82\%ash content, $2.62 \mathrm{mg} / 100 \mathrm{~g}$ anthocyanin, $16.07 \%$ sugar reduction content, color liked, flavor grape skins medium and liked, texture very chewy and liked, strong sweet taste and rather liked and overall acceptance liked.
\end{abstract}

Keywords : Carrageenan, Grape skins, Jelly candy

\section{PENDAHULUAN}

Anggur bali (Vitis vinifera) varietas Alphonse lavallee merupakan anggur lokal yang banyak dikembangkan sejak tahun 1974 di Buleleng, Singaraja. Pengolahan anggur bali biasanya hanya diproses menjadi red wine dan memiliki hasil samping berupa kulit anggur. Kulit anggur merupakan limbah industri pengolahan anggur yang selama ini hanya dimanfaatkan sebagai pakan ternak dan dibuang begitu saja. Limbah kulit anggur berpotensi dalam pembuatan makanan atau minuman yang bermanfaat karena mengandung senyawa antosianin. Antosianin merupakan senyawa fenolik golongan flavonoid yang memberikan warna merah dan ungu pada buah dan sayur. Menurut Setiawati (2017) kulit anggur yang diolah menjadi jelly drink memiliki kandungan antosianin berkisar antara 2,60 mg/100g - 3,90 mg/100g. Kulit anggur saat ini masih belum dimanfaatkan secara optimal, sehingga perlu pengolahan lebih lanjut agar kulit anggur memiliki nilai ekonomis yang tinggi. Salah satu produk olahan yang bisa dikembangkan adalah permen jelly kulit anggur hitam.

Permen jelly adalah salah satu produk pangan yang sangat digemari oleh masyarakat terutama anak-anak. Permen jelly termasuk dalam makanan semi basah yang dibuat dari sari buah dan bahan pembentuk gel, dengan kenampakan jernih dan transparan, serta mempunyai tekstur 
dan kekenyalan tertentu (Harijono et al., 2001). Menurut Malik (2010), permen jelly dengan mutu yang baik memiliki ciri-ciri yaitu berpenampilan jernih dan transparan, bertekstur kenyal, elastis, manis dan sedikit asam, serta beraroma buah segar.

Pemanfaatan kulit anggur hitam menjadi permen jelly ini dapat dilakukan karena kulit anggur hitam memiliki kandungan antosianin yang tinggi sehingga dapat dimanfaatkan sebagai sari buah alami dalam pembuatan permen jelly. Pewarna alami pada kulit anggur berpotensi memberikan warna yang menarik yaitu berwarna ungu kemerahan dan aroma yang khas pada permen jelly yang dihasilkan.

Salah satu faktor yang mempengaruhi mutu permen jelly adalah adanya bahan pembentuk gel. Permen jelly pada umumnya dibuat dengan penambahan gelatin. Gelatin merupakan bahan pembentuk gel yang bersifat reversible yaitu jika gel dipanaskan akan membentuk cairan dan bila didinginkan akan membentuk gel kembali (Hambali et al., 2004). Gelatin umumnya diproduksi dari kulit atau tulang babi. Salah satu bahan pembentuk gel yang dapat digunakan selain gelatin dalam pembuatan permen jelly adalah karagenan. Penggunaan karagenan dalam pembuatan permen jelly akan menghasilkan permen jelly dengan karakteristik memiliki tekstur kokoh namun mudah dikunyah saat dimakan.
Karagenan dipilih karena memiliki peranan yang sama seperti gelatin yaitu sebagai pengental dan bahan pembentuk gel. Karagenan diperoleh dari ekstrak rumput laut merah (Rhodophyceae) dalam larutan alkali panas selama 10-30 jam kemudian diikuti dengan pengendapan menggunakan alkohol atau potassium klorida dan dikeringkan (Winarno, 1996). Karagenan mengandung natrium, magnesium, dan kalsium yang dapat terikat pada gugus ester sulfat dari galaktosa dan kopolimer 3,6-anhydro-galaktosa. Karagenan yang digunakan dalam penelitian adalah jenis kappa karagenan yang berfungsi sebagai gelling agent yang dapat memperbaiki tekstur permen jelly.

Tujuan dari penelitian ini adalah mengetahui pengaruh penambahan konsentrasi karagenan terhadap karakteristik permen jelly kulit anggur dan menentukan konsentrasi karagenan yang tepat sehingga dapat menghasilkan permen jelly dengan karakteristik terbaik.

\section{METODE PENELITIAN}

\section{Bahan dan Alat}

Bahan-bahan yang digunakan dalam melaksanakan penelitian ini terdiri dari bahan baku dan bahan kimia. Bahan baku terdiri darikulit anggur yang diperoleh dari Hatten Wine Sanur, kappa karagenan, sirup glukosa, gula pasir, asam sitrat yang diperoleh dari UD. Fenny dan air. Bahan kimia yang digunakan dalam melakukan analisis kimia meliputi $\mathrm{KCl}, \mathrm{HCl}$, asam 
sitrat, natrium sitrat, methanol, aquades, natrium karbonat anhidrat, garam rochelle, natrium bikarbonat, natrium sulfat anhidrat, $\mathrm{CuSO}_{4} .5 \mathrm{H}_{2} \mathrm{O}$, asam sulfat pekat, ammonium molybdat, $\mathrm{Na}_{2} \mathrm{Ha}_{2} \mathrm{SO}_{4} 7 \mathrm{H}_{2} \mathrm{O}$, larutan glukosa.

Alat yang digunakan untuk membuat permen jelly adalah pisau, waskom, panci, kukusan, blender (Philips), timbangan digital (ACIS), gelas ukur (Pyrex), cetakan, kompor gas (Rinnai), wajan, loyang, kertas roti dan oven. Alat yang digunakan untuk analisis sifat fisik dan kimia adalah lumpang, kertas saring, corong, eksikator, cawan porselin, botol timbang, oven (Memmert), timbangan analitik (Shimadzu), aluminium foil, pinset, muffle (Daihan), kompor listrik, pipet tetes, gelas beaker (Pyrex), gelas ukur (Pyrex), pipet volume (Pyrex), pompa karet, labu takar (Pyrex), tabung reaksi (Pyrex), vortex (Maxi Mix II Type 367000), mikropipet (Socorex), tip, cuvett (Quartz),spektrofotometer

(Thermo

Scientific Genesis $10 S$ UV-Vis), perangkat komputer dan lembar quisioner.

\section{Pelaksanaan Penelitian}

Pembuatan permen jelly kulit anggur mengacu pada penelitian yang telah dilakukan oleh Ariyoga (2016) dengan modifikasi. Proses Pembuatan permen jelly kulit anggur dimulai dengan pembuatan sari kulit anggur. Kulit anggur disortasi untuk memisahkan bijinya, dilakukan pencucian dan di blansing dengan metode steam pada suhu $60^{\circ}$ Cselama 3 menit. Selanjutnya ditimbang sebanyak 100gr. Kemudian dihaluskan menggunakan blender dengan penambahan air (1:1). Bubur kulit anggur kemudian disaring dengan kain saring untuk memisahkan antara ampas dengan fitratnya. Sari kulit anggur ditimbang sebanyak 100g, kemudian dicampur dengan sirup glukosa $10 \%$, gula pasir $25 \%$ dan ditambahkan karagenan sesuai perlakuan $(1,0 \%, 1,5 \%, 2,0 \%, 2,5 \%, 3,0 \%$ dan $3,5 \%)$. Pencampuran bahan disertai dengan pengadukan agar semua bahan tercampur.Pemanasan dilakukan dengan metode steam selama 5 menit hingga suhu $80^{\circ} \mathrm{C}$ dengan pengadukan hingga bahan mengental. Setelah proses pemasakan kemudian ditambah asam sitrat 0,5\%. Adonan kemudian dituang dalam cetakan berukuran $(10 \times 5 \times 1 \mathrm{~cm})$ dan didiamkan selama 1 jam agar memadat. Permen jelly yang telah memadat kemudian dilakukan pemotongan ukuran $2 \times 1 \times 1 \mathrm{~cm}$ dan disusun rapi dalam loyang yang telah dilapisi kertas roti agar pada saat pengovenan permen tidak lengket. Selanjutnya dikeringkan menggunakan oven pada suhu $60^{\circ} \mathrm{C}$, selama 8 jam. Permen jelly yang telah di oven kemudian dimasukkan dalam wadah dan disimpan dalam lemari pendingin selama 5 jam untuk memaksimalkan tekstur permen jelly.

\section{Parameter yang Diamati}

Variabel yang diamati dalam penelitian ini meliputi kadar air dengan metode 
pengeringan (Sudarmadji et al., 1997), kadar abu dengan metode pengabuan (Sudarmadji et al., 1997), kadar antosianin pH differensial (Lee, 2005), kadar gula reduksi dengan metode Nelson Somogyi (Sudarmadji et al., 1997) dan evaluasi sensoris menggunakan uji hedonik terhadap warna, aroma, tekstur, rasa dan penerimaan keseluruhan serta uji skoring terhadap aroma, tekstur dan rasa (Soekarto, 1985).

\section{HASIL DAN PEMBAHASAN}

Hasil analisis kadar air, kadar abu, total antosianin, gula reduksi dan uji kekenyalan dari permen jelly kulit anggur dapat dilihat pada Tabel 1.

\section{Kadar Air}

Hasil sidik ragam menunjukkan bahwa penambahan konsentrasi karagenan berpengaruh sangat nyata $(\mathrm{P}<0,01)$ terhadap kadar air permen jelly kulit anggur. Tabel 1 menunjukkan bahwa kadar air pada permen jelly kulit anggur berkisar antara 16,58\% $18,62 \%$. Nilai rata-rata kadar air permen jelly terendah diperoleh pada perlakuan P6 yaitu 16,58\%. Kadar air permen jelly tertinggi diperoleh pada perlakuan P1 yaitu $18,62 \%$ serta tidak berbeda dengan perlakuan P2.

Tabel 1 menunjukkan bahwa semakin tinggi konsentrasi karagenan yang ditambahkan, kadar air permen jelly kulit anggur yang dihasilkan semakin rendah. Hal ini disebabkan karena karagenan berfungsi sebagai pengental yang memiliki kemampuan untuk mengikat air. Hal ini didukung oleh pernyataan Estiasih dan Ahmadi (2009), bahwa karagenan sebagai pengental yang ditambahkan ke dalam bahan makanan dapat meningkatkan viskositas bahan dan mengurangi kadar air. Semakin tinggi konsentrasi karagenan yang ditambahkan di dalam bahan makanan maka jumlah padatan akan semakin banyak dan kadar air bahan akan semakin menurun. Kadar air permen jelly kulit anggur dari hasil penelitian ini telah memenuhi standar mutu (SNI 3547-2-2008) permen jelly yaitu maksimal 20\%.

Tabel 1. Nilai rata-rata Kadar Air, Kadar Abu, Total Antosianin dan Gula Reduksi Permen Jelly kulit Anggur

\begin{tabular}{ccccc}
\hline $\begin{array}{c}\text { Konsentrasi } \\
\text { Karagenan }\end{array}$ & $\begin{array}{c}\text { Kadar } \\
\text { Air }(\%)\end{array}$ & $\begin{array}{c}\text { Kadar Abu } \\
(\%)\end{array}$ & $\begin{array}{c}\text { Total Antosianin } \\
(\mathrm{mg} / 100 \mathrm{~g})\end{array}$ & $\begin{array}{c}\text { Gula Reduksi } \\
(\%)\end{array}$ \\
\hline $1,0 \%(\mathrm{P} 1)$ & $18,62 \mathrm{a}$ & $0,68 \mathrm{e}$ & $2,82 \mathrm{a}$ & $14,01 \mathrm{~d}$ \\
$1,5 \%(\mathrm{P} 2)$ & $18,49 \mathrm{a}$ & $0,75 \mathrm{de}$ & $2,79 \mathrm{a}$ & $15,08 \mathrm{~cd}$ \\
$2,0 \%(\mathrm{P} 3)$ & $18,01 \mathrm{~b}$ & $0,82 \mathrm{~d}$ & $2,62 \mathrm{a}$ & $16,07 \mathrm{c}$ \\
$2,5 \%(\mathrm{P} 4)$ & $17,45 \mathrm{c}$ & $0,99 \mathrm{c}$ & $2,52 \mathrm{a}$ & $18,22 \mathrm{~b}$ \\
$3,0 \%(\mathrm{P} 5)$ & $17,17 \mathrm{c}$ & $1,21 \mathrm{~b}$ & $2,03 \mathrm{~b}$ & $20,59 \mathrm{a}$ \\
$3,5 \%(\mathrm{P} 6)$ & $16,58 \mathrm{~d}$ & $1,42 \mathrm{a}$ & $1,80 \mathrm{~b}$ & $21,13 \mathrm{a}$ \\
\hline
\end{tabular}

Keterangan: Nilai rata - rata yang diikuti oleh huruf yang berbeda pada kolom yang sama menunjukkan berbeda nyata pada Uji Duncan $\mathrm{P}<0,05$. 


\section{Kadar Abu}

Hasil sidik ragam menunjukkan bahwa penambahan konsentrasi karagenan berpengaruh sangat nyata $(\mathrm{P}<0,01)$ terhadap kadar abu permen jelly. Tabel 1 menunjukkan bahwa kadar abu pada permen jelly kulit anggur berkisar antara $0,68 \%-1,42 \%$. Nilai rata-rata kadar abu permen jelly terendah diperoleh pada perlakuan P1 yaitu $0,68 \%$ serta tidak berbeda dengan perlakuan P2. Kadar abu permen jelly tertinggi diperoleh pada perlakuan P6 yaitu 1,42\%. Kadar abu semakin meningkat dengan semakin banyaknya karagenan yang ditambahkan pada pembuatan permen jelly, hal ini dipengaruhi oleh kandungan mineral yang terdapat pada kappa karagenan yang digunakan. Menurut Santoso et al. (2004) kadar mineral pada Kappaphycus alvareisi terdiri dari magnesium $2,9 \mathrm{mg} / \mathrm{g}$, kalsium 2,8 mg/g, kalium $87,1 \mathrm{mg} / \mathrm{g}$, dan natrium $11,9 \mathrm{mg} / \mathrm{g}$.

Hal ini sejalan dengan pernyataan Sukri (2006), semakin tinggi konsentrasi karagenan yang ditambahkan maka kadar abu permen jelly semakin meningkat karena karagenan dibuat dari rumput laut yang termasuk dalam bahan pangan yang mengandung mineral yang cukup tinggi. Menurut Santoso et al. (2004) dalam basis kering, mineral yang terkandung dalam karagenan mencapai 10,47\%. Milani dan Maleki (2012) bahwa karagenan mampu membentuk jala tiga dimensi. Jala tiga dimensi ini dapat mengikat kandungan mineral pada produk sehingga mineral yang terkandung dapat dipertahankan. Kadar abu yang dihasilkan dalam permen jelly kulit anggur dari hasil penelitian ini telah memenuhi standar mutu (SNI 3547-2-2008) permen jelly yaitu maksimal $3 \%$.

\section{Total Antosianin}

Hasil sidik ragam menunjukkan bahwa penambahan konsentrasi karagenan berpengaruh sangat nyata $(\mathrm{P}<0,01)$ terhadap karakteristik permen jelly kulit anggur. Tabel 1 menunjukkan bahwa total antosianin pada permen jelly kulit anggur berkisar antara 2,82 $\mathrm{mg} / 100 \mathrm{~g}-1,80 \mathrm{mg} / 100 \mathrm{~g}$. Nilai rata-rata total antosianin permen jelly terendah diperoleh pada perlakuan P6 yaitu $1,80 \mathrm{mg} / 100 \mathrm{~g}$ serta tidak berbeda dengan perlakuan P5. Total antosianin permen jellytertinggi diperoleh pada perlakuan $\mathrm{P} 1$ yaitu $2,82 \mathrm{mg} / 100 \mathrm{~g}$ serta tidak berbeda dengan perlakuan P2, P3 dan P4 . Hasil analisis bahan baku menunjukkan bahwa total antosianin kulit anggur sebesar $161,95 \mathrm{mg} / 100 \mathrm{~g}$. Total antosianin semakin menurun seiring dengan penambahan karagenan. Hal ini dikarenakan karagenan tidak mengandung antosianin. Menurut Purnomo (2014) penurunan kadar antosianin seiring dengan ditambahkannya konsentrasi karagenan diduga karagenan dapat meningkatkan viskositas produk. Viskositas atau kekentalan yang terlalu tinggi menyebabkan degradasi senyawa antosianin yang lebih banyak.

\section{Gula Reduksi}

Salah satu parameter penting dalam penentuan karakteristik mutu permen adalah 
gula reduksi. Hasil sidik ragam menunjukkan bahwa penambahan konsentrasi karagenan berpengaruh sangat nyata $(\mathrm{P}<0,01)$ terhadap kadar gula reduksi permen jelly kulit anggur. Tabel 1 menunjukkan bahwa kadar gula reduksi pada permen jelly kulit anggur berkisar antara $14,01 \%-21,13 \%$. Kadar gula reduksi permen jelly terendah diperoleh pada perlakuan P1 yaitu 14,01\% serta tidak berbeda dengan perlakuan P2. Kadar gula reduksi permen jelly tertinggi diperoleh pada perlakuan P6 yaitu 21,13\% serta tidak berbeda dengan perlakuan P5. Berdasarkan analisis bahan baku karagenan mengandung gula reduksi lebih besar dari kulit anggur yaitu $3,94 \%$.

Semakin tinggi konsentrasi karagenan yang ditambahkan, maka gugus reduktifnya semakin tinggi sehingga gula reduksi yang dihasilkan akan meningkat. Hal ini sesuai dengan pendapat Winarno (1990), karagenan merupakan polisakarida yang linier atau lurus dan merupakan molekul galaktan dengan unitunit utamanya adalah galaktosa. Ada tidaknya sifat pereduksi dari suatu molekul ditentukan oleh ada tidaknya gugus hidroksil $(\mathrm{OH})$ bebas yang reaktif (Winarno, 1992). Gula reduksi yang dihasilkan dalam permen jelly kulit anggur hitam dari hasil penelitian ini telah memenuhi standar mutu (SNI 3547-2-2008) permen jelly yaitu maksimal $25 \%$.

\section{Evaluasi Sifat Sensoris}

Nilai rata-rata uji hedonik terhadap warna, aroma, tekstur, rasa dan penerimaan keseluruhan permen jelly dapat dilihat pada Tabel 2. Nilai rata-rata uji skoring terhadap aroma, tekstur dan rasa dapat dilihat pada pada Tabel 3.

\section{Warna}

Hasil sidik ragam menunjukkan bahwa penambahan konsentasi karagenan berpengaruh tidak nyata $(\mathrm{P}>0,05)$ terhadap warna permen jelly. Tabel 2 menunjukkan bahwa nilai rata-rata tingkat kesukaan panelis terhadap warna permen jelly berkisar antara5,35 (agak suka) sampai dengan5,60 (suka). Penambahan karagenan dengan konsentrasi yang berbeda berdasarkan pengujian hedonik menghasilkan pengaruh yang tidak nyata, Hal ini disebabkan karena permen jelly yang dihasilkan mempunyai warna yang sama yaitu ungu.Konsentrasi karagenan memberikan pengaruh tidak berbeda nyata pada uji organoleptik warna. 
Tabel 2. Nilai rata - rata Uji Hedonik Warna, Aroma, Tekstur, Rasa dan Penerimaan Keseluruhan Permen Jelly

\begin{tabular}{lccccc}
\hline \multirow{2}{*}{$\begin{array}{l}\text { Konsentrasi } \\
\text { Karagenan }\end{array}$} & Warna & Aroma & Tekstur & Rasa & $\begin{array}{c}\text { Penerimaan } \\
\text { Keseluruhan }\end{array}$ \\
\cline { 2 - 6 } & $5,60 \mathrm{a}$ & $5,30 \mathrm{a}$ & $5,35 \mathrm{a}$ & $5,00 \mathrm{a}$ & $5,40 \mathrm{a}$ \\
& $5,60 \mathrm{a}$ & $5,35 \mathrm{a}$ & $5,40 \mathrm{a}$ & $5,10 \mathrm{a}$ & $5,45 \mathrm{a}$ \\
$1,0 \%(\mathrm{P} 1)$ & $5,60 \mathrm{a}$ & $5,50 \mathrm{a}$ & $5,60 \mathrm{a}$ & $5,25 \mathrm{a}$ & $5,70 \mathrm{a}$ \\
$2,0 \%$ (P2) & $5,55 \mathrm{a}$ & $5,45 \mathrm{a}$ & $5,55 \mathrm{a}$ & $5,20 \mathrm{a}$ & $5,65 \mathrm{a}$ \\
$2,5 \%$ (P4) & $5,35 \mathrm{a}$ & $5,20 \mathrm{a}$ & $3,95 \mathrm{~b}$ & $4,95 \mathrm{a}$ & $4,85 \mathrm{~b}$ \\
$3,0 \%$ (P5) & $5,35 \mathrm{a}$ & $5,25 \mathrm{a}$ & $3,75 \mathrm{~b}$ & $4,95 \mathrm{a}$ & $4,75 \mathrm{~b}$ \\
$3,5 \%(\mathrm{P} 6)$ & & &
\end{tabular}

Keterangan: Nilai rata - rata yang diikuti oleh huruf yang berbeda pada kolom yang sama menunjukkan berbeda nyata pada Uji Duncan $\mathrm{P}<0,05$.

Kriteria hedonik : 1 (sangat tidak suka), 2 (tidak suka), 3 (agak tidak suka), 4 (biasa), 5 (agak suka), 6 (suka), 7 (sangat suka).

Tabel 3. Nilai rata-rata Uji Skoring Aroma, Tekstur dan Rasa Permen Jelly

\begin{tabular}{lccc}
\hline \multirow{2}{*}{ Konsentrasi Karagenan } & \multicolumn{3}{c}{ Nilai rata - rata uji skoring } \\
\cline { 2 - 4 } & Aroma Kulit Anggur & $\begin{array}{c}\text { Tekstur Permen } \\
\text { Jelly }\end{array}$ & Rasa Permen Jelly \\
\hline $1,0 \%$ (P1) & $3,10 \mathrm{a}$ & $3,50 \mathrm{~b}$ & $3,95 \mathrm{a}$ \\
$1,5 \%$ (P2) & $3,05 \mathrm{a}$ & $3,50 \mathrm{~b}$ & $3,95 \mathrm{a}$ \\
$2,0 \%$ (P3) & $3,00 \mathrm{a}$ & $3,95 \mathrm{a}$ & $4,05 \mathrm{a}$ \\
$2,5 \%$ (P4) & $3,00 \mathrm{a}$ & $3,70 \mathrm{ab}$ & $4,00 \mathrm{a}$ \\
$3,0 \%$ (P5) & $2,85 \mathrm{a}$ & $1,95 \mathrm{c}$ & $4,05 \mathrm{a}$ \\
$3,5 \%$ (P6) & $2,80 \mathrm{a}$ & $1,90 \mathrm{c}$ & $4,05 \mathrm{a}$ \\
\hline
\end{tabular}

Keterangan: Nilai rata - rata yang diikuti oleh huruf yang berbeda pada kolom yang sama menunjukkan berbeda nyata pada Uji Duncan $\mathrm{P}<0,05$.

Kriteria aroma : 1 (tidak beraroma kulit anggur), 2 (aroma kulit anggur lemah), 3 (aroma kulit anggur sedang), 4 (aroma kulit anggur kuat), 5 (aroma kulit anggur sangat kuat).

Kriteria tekstur : 1 (tidak kenyal), 2 (agak kenyal), 3 (kenyal), 4 (sangat kenyal), 5 (amat sangat kenyal).

Kriteria rasa : 1 (tidak berasa manis), 2 (rasa manis lemah), 3 (rasa manis sedang), 4 (rasa manis kuat), 5 (rasa manis sangat kuat).

\section{Aroma}

Hasil sidik ragam menunjukkan bahwa peningkatan konsentrasi karagenan berpengaruh tidak nyata $(\mathrm{P}>0,05)$ terhadap kesukaan aroma (uji hedonik) permen jelly. Tabel 2 menunjukkan bahwa nilai rata-rata tingkat kesukaan panelis terhadap aroma permen jelly berkisar antara 5,20 (agak suka) sampai dengan5,50 (suka). Penambahan konsentrasi karagenan berpengaruh tidak nyata
$(\mathrm{P}>0,05)$ terhadap tingkatan aroma (uji skoring) permen jelly. Tabel 3 menunjukkan bahwa nilai rata-rata penerimaan terhadap aroma uji skoring berkisar antara 2,80 - 3,10 (aroma kulit anggur sedang). Panelis menyukai permen jelly dengan aroma kulit anggur sedang. Penambahan zat-zat hidrokoloid seperti karagenan dapat mengurangi aroma pada produk (Winarno, 1997). 


\section{Tekstur}

Hasil sidik ragam menunjukkan bahwa peningkatan konsentrasi karagenan berpengaruh sangat nyata $(\mathrm{P}<0,01)$ terhadap kesukaan tekstur (uji hedonik) permen jelly. Tabel 2 menunjukkan bahwa nilai rata-rata tingkat kesukaan panelis terhadap tekstur permen jelly berkisar antara 3,75 (biasa) sampai dengan 5,60 (suka). Peningkatan konsentrasi karagenan berpengaruh sangat nyata $(\mathrm{P}<0,01)$ terhadap tingkatan tekstur (uji skoring) permen jelly. Tabel 3 menunjukkan bahwa nilai rata-rata penerimaan terhadap tekstur uji skoring permen jelly berkisar antara 1,90 (agak kenyal) sampai dengan 3,95 (sangat kenyal).

Terdapat pengaruh yang nyata dari penambahan konsentrasi karagenan terhadap tingkat kesukaan tekstur permen jelly. Panelis menyukai permen jelly pada perlakuan penambahan karagenan 2\% dengan tekstur sangat kenyal. Tingkat penerimaan panelis terendah ada pada penambahan karagenan $3,5 \%$. Hal ini dikarenakan konsentrasi karagenan yang tinggi menyebabkan tekstur permen jelly menjadi kokoh. Karagenan memiliki kekuatan gel yang lebih kuat dari gelatin (Eveline et al., 2009).

\section{Rasa}

Hasil sidik ragam menunjukkan bahwa penambahan konsentrasi karagenan berpengaruh tidak nyata $(\mathrm{P}>0,05)$ terhadap rasa permen jelly. Tabel 2 menunjukkan bahwa nilai rata-rata tingkat kesukaan panelis terhadap rasa permen jelly berkisar antara 4,95 - 5,25 (agak suka). Pengaruh penambahan konsentrasi karagenan berpengaruh tidak nyata ( $P>0,05)$ terhadap tingkatan rasa (uji skoring) permen jelly. Tabel 3 menunjukkan bahwa nilai rata-rata penerimaan terhadap rasa uji skoring permen jelly berkisar antara 3,95 4,05 (rasa manis kuat). Panelis agak menyukai permen jelly dengan rasa manis kuat.

Rasa dipengaruhi oleh beberapa faktor, yaitu senyawa kimia, suhu, konsentrasi, dan interaksi dengan komponen rasa yang lain. Sukrosa dan sirup glukosa menghasilkan rasa manis dalam permen jelly, sedangkan rasa asam diperoleh dari kulit anggur dan penambahan asam sitrat. Permen jelly kulit anggur dibuat dengan penambahan jumlah sukrosa, sirup glukosa, dan asam dalam jumlah yang sama. Semakin banyak penambahan karagenan cenderung memberikan manis lebih kuat. Hal ini sesuai dengan pendapat Harijono et al., (2001) yang menyatakan peningkatan jumlah karagenan yang tinggi disukai panelis karena karagenan menghasilkan gel yang kuat dan rasa yang sangat manis.

\section{Penerimaan Keseluruhan}

Hasil sidik ragam menunjukkan bahwa penambahan konsentrasi karagenan berpengaruh nyata $(\mathrm{P}<0,05)$ terhadap penerimaan keseluruhan permen jelly. Tabel 2 menunjukkan bahwa nilai rata-rata tingkat kesukaan panelis terhadap penerimaan keseluruhan permen jelly berkisar antara 4,75 (agak suka) sampai dengan 5,70 (suka). Penerimaan keseluruhan permen jelly dipengaruhi oleh beberapa faktor seperti warna, aroma, tekstur dan rasa. 


\section{KESIMPULAN DAN SARAN}

\section{Kesimpulan}

1. Penambahan konsentrasi karagenan berpengaruh terhadap kadar air, kadar abu, total antosianin, kadar gula reduksi, kesukaan tekstur (uji hedonik dan uji skoring), dan penerimaan keseluruhan (uji hedonik) permen jelly kulit anggur.

2. Penambahan karagenan dengan konsentrasi 2,0\% merupakan karakteristik terbaik permen jelly kulit anggur dengan kriteria kadar air (18,01\%), kadar abu $(0,82 \%)$, total antosianin $(2,52 \mathrm{mg} / 100 \mathrm{~g})$, gula reduksi $(16,07 \%)$, warna suka, aroma kulit anggur sedang dan suka, tekstur sangat kenyal dan suka, rasa manis kuat dan agak suka serta penerimaan keseluruhan suka.

\section{Saran}

1. Berdasarkan hasil penelitian, untuk menghasilkan permen jellyterbaik disarankan menggunakan penambahan 2,0\% karagenan. Perlu dilakukan lagi penelitian lanjutan dengan penggunaan bahan pembentuk gel lain yang meningkatkan karakter fisik permen jelly.

\section{DAFTAR PUSTAKA}

Anonimous. 2008. SNI 3547-2-2008. Kembang Gula Lunak. Departemen Perindustrian dan Perdagangan.

Ariyoga, U. 2016. Karakterisasi dan formulasi Permen Jelly Pisang Raja Sereh (Musa sapientum L). Skripsi. Jurusan Teknologi Hasil Pertanian. Fakultas
Teknologi Pertanian. Universitas Jember.

Estiasih, T., dan K, Ahmadi. 2009. Teknologi Pengolahan Pangan. Bumi Aksara, Jakarta.

Eveline., J, Santoso., dan I, Widjaya. 2009. Pengaruh Konsentrasi dan Rasio Gelatin dari Kulit Ikan Patin dan Kappa Karagenan dari Eucheuma cottoni pada Pembuatan Jeli. Jurnal Ilmu dan Teknologi Pangan, 7(2): 55-75.

Gani, A., $2010 . \quad$ Mikrobiologi Sederhana.Bandung : $\quad$ Penerbit Swabaya Media Utama.

Gomez, K. A. dan A. A. Gomez. 1995. Prosedur Statistik Untuk Penelitian Pertanian. UI- Press, Jakarta.

Hambali, E., A. Suryani dan N. Widianingsih. 2004. Membuat Aneka Olahan Mangga. Penebar Swadaya. Jakarta.

Harijono., J, Kusnadi., dan S.A. Mustikasari. 2001. Pengaruh Kadar Karagenan dan Total Padatan Terlarut Sari Buah Apel Muda Terhadap Aspek Kualitas Permen Jelly. Jurnal Teknologi Pertanian, 7(2): 55-75.

Lee, J. 2005. Determination of Total Monomeric Anthocyanin Pigment Content of Fruit Juice, Beverages, Natural Colorants, and Wines by the $\mathrm{pH}$ Differential Method: Collaboration Study. JournaL of AOAC International, $88(5): 1269$.

Malik, I. 2010. Permen Jelly.iwan malik. wordpress.com/2010/04/22/permenjelly/. Diakses pada tanggal 01 mei 2017

Milani, J. dan G, Maleki. 2012. Food Industrial Processes - Methods and Equipment. InTech, Croatia.

Purnomo, O.K. 2014. Pembuatan minuman Prebiotik Sari Bunga Roselle (Hibiscus Sabdariffa L.). Skripsi. FTP. Unibraw. Malang

Santoso, J., Y, Yumiko., dan S, Takeshi. 2004. Komposisi mineral, asam lemak, dan serat pada beberapa jenis rumput laut Indonesia. Jurnal Ilmu Perairan dan Perikanan Indonesia. ISSN 0854-3194. 11(1):45-51 
Setiawati, I. 2017. pemanfaatan limbah kulit anggur lokal dalam pembuatan jelly drink. Skripsi. FTP. Unud.Jimbaran.

Soekarto, S.T. 1985. Penilaian Organoleptik Untuk Pangan dan Hasil Pertanian. Bhratara Karya Aksara, Jakarta.

Sudarmadji, S., B. Haryono dan Suhardi. 1997. Prosedur Analisa Bahan Makanan dan Pertanian. Liberty. Yogyakarta.

Sukri, N. 2006.Karakteristik Alkali Tread Cottoni (ATC) dan Karaginan Dari
Rumput Laut Euchema cottoni Pada Umur Panen yang Berbeda. Program Studi Teknologi Hasil Perikanan. Fakultas Perikanan dan Ilmu Kelautan.Institut Pertanian Bogor.

Winarno, F. G. 1990. Teknologi Pengolahan Rumput Laut. Pustaka Sinar Harapan, Jakarta

Winarno, F.G. 1992. Kimia Pangan dan Gizi, Gramedia, Jakarta

Winarno, F.G., 1997. Kimia Pangan dan Gizi. Gamedia Pustaka Utama, Jakarta. 